\title{
Towards a Narrative Understanding of Thomistic Natural Law
}

\author{
PAMELA M. HALl
}

I wish to discuss Thomistic ethics in this essay in a way that seeks to integrate Aquinas's natural law teaching with his treatment of the virtues, most particularly with the virtue of prudentia or practical wisdom. ${ }^{1}$ Natural law's importance in the moral philosophy of Saint Thomas has been given undue and autonomous emphasis in my view; I want to make a case that any account of natural law that neglects the role of practical wisdom-and of the other virtues as well-in the natural law's development and application simply falls into incoherence. But there have been philosophers who have seen problems with reconciling practical wisdom and the natural law within Aquinas's moral teaching, and I will begin with a discussion of some of the difficulties they have seen. ${ }^{2}$

1. Prudentia is the Latin translation of Aristotle's phronesis. I take the term "practical wisdom" to best translate phronesis and prudentia, words that, as I say below, are roughly synonymous; I suggest some differences later in my essay. When I use the English word "prudence," I mean it as a synonym for Thomas's prudentia.

2. In the discussion that follows, I will restrict comment to only a few philosophers writing on Aristotle and Aquinas. Of course, a massive body of scholarship addresses Aristotle's ethics as well as Thomas's natural law theory. It is my desire in this essay to speak incisively and clearly about a specific set of issues. I believe this can best be done by addressing the primary texts in Aquinas himself, without repeated 
Students of Aquinas have long been troubled by apparent incompatibilities between Thomistic and Aristotelian ethics. Foremost among these incompatibilities is the tension between the standards of right action that they employ. Aristotle holds phronesis, the practical wisdom of the fully virtuous person, to be the chief determinant of right action; further, he says very little, and that little is obscure, about natural or nonconventional justice. Aquinas, on the other hand, propounds the doctrine of natural law precisely in order to describe a nonconventional standard of justice accessible to all rational creatures. In this context Thomas recalls the remarks of Paul in Romans 2:14: "where the gentiles who have not the law do by nature those things that are of the law." 3 Aquinas sees this Pauline teaching as presupposing a natural law, one consistent with divine law but not requiring special revelation. Aristotle and Aquinas thus appear to hold different, and perhaps incompatible, standards of justice. This difference of opinion goes beyond a possible disagreement between Aquinas and the pagan philosopher he so esteemed; Thomas imports the standard of practical wisdom, what he calls "prudence," into his own ethics. There then look to be two distinct standards of right action within Thomistic ethics itself. If these standards are separate and unintegrated, Thomas faces the charge of a naive or immature eclecticism. If these standards are not only separate but incompatible, Thomas faces the far more serious charge of internal inconsistency. What I want to defend is an interpretation of Aquinas that reconciles practical wisdom and the natural law; such an account may also render his ethics more deeply Aristotelian than it is sometimes taken to be. ${ }^{4}$

reference to other interpretations and perspectives. I invite Nussbaum and Goerner into the discussion because their particular interpretations, which are also concerned with connections between practical wisdom and law in some sense, help to draw out important issues that I wish to address. I do not pretend, of course, that theirs are the only important interpretations of Aristotelian practical wisdom or of Thomistic natural law.

3. Quoted by Thomas in the Summa theologiae 1-2.91.2. Translations from the Summa are my own unless otherwise noted. The Latin text from which I am working is that of the Leonine edition of Opera omnia (Rome, 1882- ).

4. In all of this presentation, I acknowledge my indebtedness to Alasdair MacIntyre, whose discussion of these issues in chapters 9 and 10 of Whose Justice? Which Rationality? (Notre Dame: University of Notre Dame Press, 1988) taught me a great deal. 
Let me now describe further the potential incompatibilities between prudence and natural law.

I am taking Aristotelian phronesis, roughly synonymous with Thomistic "prudence," to be a capacity for judgment in individual cases that takes account of the particular circumstances of each situation. This excellence is dependent, as are all the virtues on Aristotle's view, on the proper early moral education provided by the community of the polis. Well-developed phronesis is the virtue that completes all the other virtues. That is to say, it makes out of what is originally mere habituation, the stuff of early moral training, ${ }^{5}$ action that is rational and fully deliberate. Practical wisdom governs an agent's deeds in such a way that he or she always acts to achieve the good in individual circumstances. It thus perfects all other virtues because it determines their exercise at any particular time; for this reason the other virtues are immature and, as it were, without proper counsel if phronesis is lacking. While desire for the proper end is secured by habituation primarily, these ends would never be achieved without the deliberations of phronesis regarding the means to those ends. ${ }^{6}$ Further, the virtuous agent possessed of practical wisdom recognizes the good that he or she seeks to achieve as good; this is to say that the phronetic person sees the point of his or her earlier habituation. What I want to emphasize in this short summary of Aristotelian teaching are the following points. First, phronesis is chiefly a capacity for judgment about how to achieve the good with respect to a particular circumstance, i.e., it must needs attend to particulars in securing these means. Second, its development presupposes the moral training provided by a specific kind of community, the polis; this training sets the ends at which phronetic deliberation aims. Yet only with the acquisition of practical wisdom comes a right appreciation of the goods into desire of which the agent has been habituated.

Let me now proceed to a brief exposition of Thomistic natural law. In doing so, I will postpone more sophisticated exegesis until later. I take what I will say here to be more or less uncontroversial, i.e., to be acceptable according to most understandings of Thomistic natural law. I base my remarks chiefly on that section of the prima

5. See Nicomachean Ethics 2.3.1104b9-13. The translation is my own.

6. See Nicomachean Ethics 6.13.1145a5-6. 
secundae of the Summa theologiae that treats of laws; I will refer as well to other portions of the Summa. Natural law, on Aquinas's view, derives from certain claims about human nature a set of exceptionless rules with respect to types of actions. ${ }^{7}$ If one then adopts the standard of natural law, one must ignore all but the relevant type-differences when deliberating about actions in any particular situation. Of course, any action and any situation can be described in an infinite number of ways; for the natural law theorist, what matters is whether or not any part of the description of a given action falls under the natural law's prohibitions or prescriptions concerning kinds of actions. For example, if a proposed action counts as a genuine instance of adultery, or murder, or lying, then that action is forbidden, on Thomas's view, no matter what additional descriptions might be supplied. There is then a prima facie philosophical incompatibility between these two standards, insofar as a morality which attends to the particulars of a situation, as does Aristotle's, might be seen to conflict with a morality that judges according to general types or categories of actions.

Lest I be accused of addressing a contrived conflict, I note here that recent philosophers have cited this difference between Aristotle and Aquinas in criticisms of Aquinas. Martha Nussbaum in particular has found fault with Thomas's rule-following ethics over and against what is on her view the superior standard of the Aristotelian virtues, with its stress on perception and moral imagination. ${ }^{8}$ On her view, an ethics of exceptionless rules must fail to do justice to the unique particulars

7. Ultimately I do not want to refute this traditional view but, rather, to reshape it; it is to the core sense of natural law, the inclinationes, that primary emphasis belongs. Traditional interpretations of Thomas's natural law theory have unduly emphasized the role that rules play and, I will argue, neglect an explanation of their origin. For the following point about crucial issues for the natural law theorist, and Thomas in particular, I am indebted to Herbert McCabe's clarity in his own formulation of this point; see his What Is Ethics All About? (Washington, D.C.: Corpus Books, 1969).

8. The dim view that Martha Nussbaum takes of Aquinas is most explicit in an early work, her commentary on Aristotle's De motu animalium (Princeton: Princeton University Press, 1978), in the essay "Practical Syllogisms and Practical Science." But her critique of any ethics employing exceptionless rules continues in even her more recent work. See her "The Discernment of Perception: An Aristotelian Conception of Private and Public Rationality," in Proceedings of the Boston Area Colloquium in Ancient Philosophy, ed. John J. Cleary, vol. 1 (Lanham, Md.: University Press of America, 1986). 
of a given situation; likewise such a system underemphasizes the role that "right emotion" must play in mature moral action. She wishes to allow for a certain "improvisation" even within rule following itself. But there are also others who, with greater sympathy for Aquinas, find the standard of natural law inferior. In his exegesis of Thomistic ethics, E. A. Goerner has stressed the superiority of practical wisdom over natural law, calling natural law "the bad man's view of Thomistic natural right." According to Goerner, natural law secures the success of divine providence by fear of penalty, through consequences that flow naturally from violations of the law. ${ }^{10}$ Practical wisdom, on the other hand, is embodied in the judgment of the virtuous person who acts through love of the good, not through fear of penalty. This standard of prudence is intrinsically superior to natural law, on his view, because of the nobler intentions of the agent and because the standard permits and requires attention to particulars. Such an attention will allow for variations on how the good is achieved; variation would not be possible should the natural law itself be taken as the primary standard of right action. Thus both Nussbaum and Goerner, from quite different starting points, find fault with the standard of Thomistic natural law understood in terms of a code of absolute rules. Nussbaum views prudence and the natural law to be separate and incompatible standards of right action. Goerner takes them to be at best functionally compatible standards, the natural law serving as a kind of initiation into the life of full virtue.

But what I am arguing for is an understanding of Thomistic natural law that in fact requires the activity of prudence in the application of the law's precepts and that requires prudence even for the discovery of the law. This issue of discovery is critical insofar as Thomas claims for this law a kind of promulgation independent of special revelation; this law must be accessible in some sense to everyone. Indeed Thomas's own general definition of "law" explicitly requires as much. In defining law per se, Aquinas assigns it four characteristics: "it is nothing else than an ordinance of reason for the common good, made by the one

9. See Goerner's "On Thomistic Natural Law," Political Theory 7 (1979): 101-122, and his "Thomistic Natural Right," Political Theory 11 (1983): 393-418.

10. For a discussion and critique of Goerner's interpretation of natural law, see my "E. A. Goerner on Thomistic Natural Law," Political Theory 18 (1990): 638-655. 
who has care of the community, and promulgated."11 Since the natural law is binding on all human beings, it needs must be satisfactorily published to them. ${ }^{12}$ Thus, in a way different from Aristotle, Aquinas wishes to make progress in the moral life available to all people, regardless of individual community or history. Not that Thomas abolishes all operative notions of community: he simply creates a new kind, a community rooted in the essential characteristics of a species.

The natural law is thus primarily, on his view, the rational creature's "participation" 13 in eternal law, the law by which God governs the entire cosmos; the community to which the natural law pertains is the community of rational creatures. Indeed, law as Thomas treats of it in the prima secundae is an analogical term, and the heart of the analogy is the eternal law. All other forms of law of which Aquinas speaks (natural, human, divine) are in one way or another related to it. I shall focus primarily on how the natural law functions as the means by which rational creatures are subject to eternal law.

What does Thomas mean when he speaks of our "participation" in eternal law? Within his initial discussion of natural law, Thomas links it chiefly with God's providential ordering of the cosmos. Natural law is what orders us to our "proper act and end" by natural inclination; 14 this is to say that natural law, whatever else it involves, is primarily how we are directed to our end, which is ultimately God. This direction is not coercive or without sense for the rational creature; Thomas calls the guidance law gives "instruction," 15 and he claims that it is the "light of natural reason," permitting us knowledge of good and evil, that so instructs us in natural law. ${ }^{16}$ Thomas's own emphasis on the natural law is in terms of inclinationes, ways of being directed to one's end, not in terms of any set of rules.

11. Summa theologiac 1-2.90.4.

12. This definition of law (in 1-2.90.4) occurs in the most general treatment of law; Thomas proceeds in subsequent questions to extend the definition in specifying laws of many different kinds. The definition, being generic, cannot be adequate for understanding any particular form of actual law.

13. Summa theologiae 1-2.91.2.

14. Summa theologiae 1-2.91.2: "per quam habet naturalem inclinationem ad debitum actum, et finem."

15. Summa theologiae 1-2.90 prologue.

16. Summa theologiae 1-2.91.2. 
All of this having been said, let me go on to flesh out my own interpretation of Thomistic natural law. I seek to bring together Aquinas's use of exceptionless rules and his new community of rational creatures within the natural law with his (more Aristotelian) emphasis on the virtues, especially the virtue of practical wisdom or prudence. I believe that the way in which Thomas speaks of natural law shows clearly that it is principally forms of directedness toward our proper ends or goods; this much has been noted already. But, and moreover, if one takes the rational character of this law seriously, then necessarily natural law also affords us understanding of the goods to which we are so directed. We must see and assent to the goods to which we are inclined by our natures. In this sense, natural law clearly is meant to have some of the components of Aristotelian phronesis, which also enables the appraisal and recognition of certain ends as good.

In question 94 of the prima secundae, Thomas discusses natural law and its most fundamental characteristics. He begins with a description of the way in which natural law is a habit; ${ }^{17}$ natural law is a habitus insofar as we hold the fundamental principles of this law by the habit of synderesis. These principles form the core knowledge of natural law within us, and these principles, held by synderesis, are "indelible," persisting in even the most vicious. ${ }^{18}$ Practical reason pertains to action, and so its first principles must pertain to what is to be sought or avoided within action.

... so good is that which first falls under the apprehension of the practical reason, which is ordered to action: since every agent acts for an end, which has the aspect of a good. Therefore, the first principle in the practical reason is that which is founded on the aspect of good, that good is that which all things desire. Hence this is the first precept of law, that good is to be done and pursued, and evil is to be avoided. ${ }^{19}$

Every rational creature has this much of an apprehension of good and evil, even babies and the damned. ${ }^{20}$ Thomas also claims that

17. Summa theologiae 1-2.94.1.

18. Summa theologiae 1-2.94.6: "Quantum ergo ad illa principia communis, lex naturalis nullo modo potest a cordibus hominum deleri in universali."

19. Summa theologiae 1-2.94.2.

20. Summa theologiae 1-2.94.1 sc. 
synderesis is infallible, ${ }^{21}$ although application of its principles can be in error. I understand by this claim of infallibility a fundamental link with synderesis and what Thomas says regarding the will: that it chooses always under the formal aspect of goodness, the ratio boni. ${ }^{22}$ I grant that this explanation of synderesis makes Aquinas's claim of synderesis's freedom from error peculiar. It may just be peculiar. I see its function as conceptual, determining how we consider actions, choices, objects of desire-i.e., in terms of goods and evils.

But why is synderesis so important for Aquinas? It is a Neoplatonic import within Aquinas's largely Aristotelian epistemology. Its presence seems therefore problematic and has certainly vexed Thomas's defenders to nightmare. ${ }^{23}$ The importance of synderesis, on my view, springs from the crucial starting point it provides for any inquirer in the moral life; it is impossible, given this capacity, for an agent completely to lack guidance in the moral life. He or she has even initially some root, inerrant apprehension of the good with which to begin the moral life and moral deliberation. We begin with at least the necessary conceptual equipment. Notice that by adopting synderesis Aquinas suggests a possible solution to a problem set him by an inadequacy (from the Christian perspective) of Aristotelian ethics: How does one make participation in the moral life available to every human being, regardless of community, and yet answer the need for moral education? One begins to do this by synderesis, which provides the most basic tutelage in reasoning about action; it secures, infallibly, that the right questions will be asked, that actions will be reasoned about under the descriptions of good or evil.

Indeed I see synderesis, when coupled with the inclinationes that are primarily the natural law, as taking the place of the Greek polis in the role of providing initial moral training of the desires. The habit of synderesis alone is by no means sufficient for ethical guidance. The forms of directedness give practical content to the conceptual

21. Summa theologiae 1.79 .12 ad 3: "quod huiusmodi incommutabiles rationes sunt prima principia operabilium, circa quae non contingit errare, et attribuuntur rationi, sicut potentiae, et synderesi sicut habitui: unde et utroque, scilicet ratione, et synderesi, naturaliter iudicamus."

22. Summa theologiae $1-2.10$ and 18 in particular.

23. Witness the cottage industry John Finnis and Germain Grisez have built up in explaining the first principles within synderesis. 
apprehensions of good and evil provided by synderesis. Thus there are on Aquinas's view activities and states that are naturally understood to be either goods or evils. This much can be counted on no matter what sort of human community it is to which one belongs. Such seems to be Thomas's claim when he says that the natural law, in its most general (communissima) principles, are known to all and cannot be erased from the human heart. ${ }^{24}$

Thomas speaks as well of the primary precepts of the natural law, which pertain to the goods to which our inclinations direct us by nature (recall this is the primary sense of "natural law" for Aquinas).

... thus it is that all those things to which the human being has a natural inclination, reason naturally apprehends as goods and consequently as things to be pursued, and their contraries as evil and things to be avoided. Therefore the order of the precepts of the natural law is according to the order of natural inclinations. ${ }^{25}$

In this secondary sense of natural law, the sense of its exceptionless rules, there are three sets of precepts according to Aquinas. ${ }^{26}$ These correspond to the hierarchy of the inclinationes themselves. First is a set of precepts governing the preservation of human life, a good that we share with all living things. Second are precepts pertaining to the begetting and rearing of offspring, a good that we share with other animals. Finally, there are precepts governing the goods to which humans incline as specifically rational beings; Thomas mentions in particular our desire "to know the truth about God and to live in society." 27 Significantly, Aquinas, in his core treatment of the contents of the natural law, does not so much as spell out some of the actual rules of the natural law. Instead, what he is concerned with is establishing a fundamental link between any precept of the natural law and the goods to which these precepts are ordered. Thomas does not here tell us which rules are necessary for human beings to achieve the good of

24. Summa theologiae 1-2.94.6. Such a claim is easy to make but hard to prove; I suspect the only sort of proof possible would be phenomenological in kind. Simone Weil, in her writings about the "human personality," might provide a good example of such a proof. See the Simone Weil Reader, ed. George A. Panichas (New York: Moyer Bell, 1977), pp. 313-339.

25. Summa theologiae 1-2.94.2.

26. Summa theologiae 1-2.94.2.

27. Summa theologiae 1-2.94.2. 
living in society; he tells us that some rules will be necessary to this end. ${ }^{28}$ I emphasize this in the light of the characterization by many philosophers of Thomas as a legalist and of his natural law as chiefly rule oriented.

In what way are these precepts arrived at? What are their actual contents? I wish to maintain that they involve an articulation of which actions are conducive towards, or destructive of, those goods to which our inclinationes direct us. They are then further articulations of what we mean by good and evil; as such, they enrich the conceptual apprehensions of good and evil afforded by synderesis. But they may also enrich our understanding of the forms of directedness themselves insofar as they specify what is minimally necessary to attain those goods of our nature; indeed, the discovery and observance of these precepts may in part constitute these goods.

This discovery of the natural law occurs by way of reflection on the goods to which we are directed by our natures and then by discovery of the necessary means for achieving or constituting these goods. I want to stress that this inquiry takes place within a life, within the narrative context of experiences that engage a moral agent's intellect and will in the making of concrete choices. In attention to what makes up one's experience and in the making of choices, both good and bad, a human being augments understanding of his or her own nature and of what most promotes the flourishing of that nature. This process of inquiry is then one of practical reasoning, practical reasoning that can be carried on individually and communally. And in so mentioning practical reasoning, I do mean to imply the operation of some measure of phronetic, i.e., of prudential, deliberation. ${ }^{29}$

Such an understanding of natural law at least escapes the pitfalls of treating the rules of the natural law as though they were self-evident; the process I am describing would be far more rough-and-ready, also

28. Bear in mind that praeceptum need not mean "precept" in our sense of an actual rule.

29. Thomas's treatment of the actual reasoning of natural law in the later articles of question 94 shows just how far his understanding of the function of natural law is from a mechanical, legalistic understanding (see, e.g., 1-2.94.4). Not only do we need prudence to apply the "rules" of the natural law, but also the principles of the natural law are very general and must be specified and amplified before they are (practically) useful in guiding actual human choices. 
far more historical. Discovery takes time. There is certainly warrant for such a reading of Aquinas, who repeatedly stresses how human custom and moral disposition can impact our knowledge of the natural law. In mentioning the "German robbers" who failed to recognize the prohibition against theft, Thomas mentions passion, evil custom, and an evil disposition of nature as damaging our ability to reason about our good. ${ }^{30}$ To assert then that reasoning about our good at all, let alone the achievement of excellence in it, is deeply influenced by personal and social history hardly seems radical. Indeed, the presence of the moral virtues also disposes us well to discovery of the law of our nature.

This understanding of natural law also emphasizes its rational character. Only by the free exercise of our practical rationality could we discover the natural law, and this discovery would involve in part doing over again the work of the first legislator, God. In that sense, God first manifests God's providence through the eternal law (in which natural law participates) and so directs all creatures to God's own self. Just so, men and women imitate (and yet obey) divine providence by directing themselves in discovering and pursuing their good. Indeed, this renders intelligible Aquinas's claim, earlier in the Summa, that human prudence is included within the providence of God. ${ }^{31}$

It is essential to note that an understanding of particular rules of the natural law, e.g., "Never murder," 32 is inseparable from an understanding of the rules' point and purpose. What the prohibition against murder prevents is the kind of disrespect for human life that would be destructive of life in community; without this law, a community could not exist in such a way as to pursue the various goods constitutive of social life. And such an understanding of the end or purpose of law can be given only by practical wisdom, on the Aristotelian and the Thomistic views. Thus to divorce natural law from the virtues is to misunderstand how both the law and the virtues

30. Summa theologiae 1-2.94.4.

31. Summa theologiae 1.22.2 ad 4. Note also that providentia and prudentia are linked etymologically. I make exactly this point as well in my critique, "E. A. Goerner on Thomistic Natural Law," p. 645.

32. I take an example from the Decalogue. Thomas notes in Summa theologiae 1-2.100.1 that the moral precepts of the Old Law really amount to the natural law, i.e., what we should have known anyway. 
conduce human beings to their proper goods and is to misunderstand how one arrives at the specific rules of the natural law in the first place. Given that only practical wisdom can yield a realization of the ends we pursue as genuine goods, some degree of it must operate in the discovery of the natural law.

Aquinas says as much in his own discussion of prudence (practical wisdom). ${ }^{33}$ Aquinas follows to some extent Aristotle when he says that moral virtue sets the ends for prudence. ${ }^{34}$ But Thomas also states that prudence relates to synderesis, as "natural reason determines the ends of the moral virtues by what is called synderesis." 35 Thus prudence ultimately takes its goals from synderesis; indeed, Thomas goes on to state that prudence reasons from synderesis, "just as understanding of [first] principles moves scientific knowledge." 36 Here he seems to me to suggest that prudence precisely involves insight into synderesis even as it reasons from it. Such a reading would be much in accord with the account I have sketched concerning our "natural" knowledge-begun in synderesis but continued by a deliberative prudence- of good and evil. Prudence on this view functions, even in imperfect exercise, within our discovery of the natural law, helping to generate the very rules it will then work to apply and extend. For no rule, let alone those of the natural law, can be applied or constituted without an accompanying understanding of the rule's point as given by practical wisdom. This is so because to know how to apply a rule or even to know which rule to apply requires the exercise of practical judgment; such judgment would have to pick out of the situation at hand the relevant particulars in order to know which rule is appropriate for it. For example, even applying a rule as absolute as the prohibition against murder requires some grasp of what constitutes murder and a grasp of which situations fall under that prohibition, a task that is not always easy. Witness contemporary debates on the ethical status of abortion, capital punishment, and nuclear deterrence. One cannot intelligently select and apply a rule without some (prudential) grasp of the good that the rule is seeking to secure or protect. And some rules must be exceptionless, for example,

33. Summa theologiae $2-2.47-50$ in particular.

34. Summa theologiae 1-2.47.2.

35. Summa theologiae 2-2.47.6 ad 1, to which compare 1.79.12.

36. Summa theologiae 2-2.47.6 ad 3. 
the rule against murder, because certain goods are so crucial for an attainment of our end and because certain actions, such as murder, operate so as to destroy these goods.

Indeed, in his discussion of the moral precepts of the Old Law, codified in the Decalogue, Thomas says that these precepts are reducible to the natural law because they are accessible to natural reason. ${ }^{37}$ The Decalogue then articulates what we should, as it were, have known anyway. He explicitly rejects the possibility that these laws could ever be dispensed with because

the precepts of the Decalogue contain the very intention of the legislator, namely God. For the precepts of the first table, which are ordered to God, contain the very order to the common and final good, which is God. The precepts of the second table contain the order of justice to be observed among human beings, namely that no one do what is undue, and that to each should be returned what is owed: for in this manner are the precepts of the Decalogue to be understood. On this account, the precepts of the Decalogue are entirely indispensable. ${ }^{38}$

It is clear in this passage that Aquinas understands the precepts of the Decalogue, also of the natural law, to be in part articulations of what virtue is as it pertains to God and to life in human community. (Recall what he says in the prima secundae 94.3 about all acts of virtue being of the natural law.) These rules do not express merely contingent means to the good; they constitute in part what it is to be just to others and to worship God rightly. When observed in the spirit of the natural law, out of the desire for the goods to which the law directs us, these rules help to specify what virtue is and observance of these rules is constitutive of virtue.

That for Aquinas phronesis and the rules of the natural law stand independent of one another cannot then be so. Neither can it be that they are incompatible. We need practical wisdom in order to discover and apply the rules of the natural law; but we also gain our knowledge of the goods to which these rules should conduce from our essential and dynamic directedness towards these goods. This directedness is Thomas's primary sense of natural law. I hope it has become clearer in what ways certain current interpretations of Aquinas fall

37. Summa theologiae 1-2.100.1.

38. Summa theologiae 1-2.100.8. 
short. Nussbaum, her emphasis on the virtues notwithstanding, fails to understand that the virtues themselves presuppose a fundamental orientation to the good; this orientation makes them means to, and also constitutive of, human flourishing. This is simply how Aquinas understands the natural law, not in terms of a code of rules. Likewise, Nussbaum fails to see in what way rule following, even of the kind she criticizes, requires some measure of prudence. A more careful reader of Aquinas but in a vein similar to Nussbaum, Goerner characterizes natural law persistently in terms of absolute rules; he, too, thereby neglects the more fundamental form of natural law in the inclinationes. By this neglect, he then fails also to see how the natural law and prudence are interdependent. Thus, by too completely severing the natural law from prudence, he does more than badly misinterpret Aquinas: he makes it impossible to understand how the natural law could function as a pedagogical tool (which is precisely the role on which Goerner lays stress). Without some understanding of the goods to which they are inclined by their natures (which would be given in prudential reflection), the Germans could never learn to recognize the "penalties" from which they suffer as penalties for the violation of the natural law. The natural law might be their scourge; it could never be their teacher.

I have thus far spoken of our knowledge of the natural law, aided by prudence, as a knowledge that is progressive and historical; we work to acquire understanding of our natures, and of the means for the flourishing of our natures, through a process of inquiry that goes on over time individually and communally. But in making this last point, I run the risk of treating natural law in isolation from another form of law from which it can never be wholly separate: human law. For human life is always lived in community, on Thomas's view, and thus the general principles of the natural law must be further articulated (and supplemented) according to the special needs of individual communities; human law is the law of specific communities. All such law should be derived from the natural law, Thomas argues. That derivation can occur in two ways:

in one way, as conclusions from principles; in another way, as determinations of certain generalities. The first way is similar to that by which 
demonstrative conclusions proceed from principles in the sciences. The second way is similar to that by which, in the arts, common forms are determined to a certain particular case. ${ }^{39}$

As an example of the first way, the way of conclusions from more general principles, Thomas offers the move from "Do harm to no one" to "Do not kill." As an example of the second way, the way of further specification, Thomas explains that while the natural law dictates that offenders should be punished, it does not say how; human law has the job of determining what the punishment should be for particular crimes.

Thus to speak of natural law as a guide for action by itself is a mistake; on Thomas's view, it is the responsibility of human law, the law of actual communities, to restate and to specify further what the natural law teaches. Indeed, natural law serves as the standard of justice for those making civil law. Thomas states that human law in discord with the natural law is "a corruption of law." 40 To go against the natural law is to act against the human good; thus, civil laws that are not ordered to the human good are, Aquinas says, more like "violence rather than laws." 41 Natural law is clearly intended to work always in tandem with human law in communities; all law is intended to make people good, Thomas says, ${ }^{42}$ and both the natural law and human law command acts of all the virtues. ${ }^{43}$

Thus in his treatment of the human law Thomas again acknowledges the specific social forms of human life; natural law does not work in isolation, as a generic, and wholly adequate, moral standard applied in the same way across all communities. Instead, natural law requires further specificity in order to be effective as a guide to right action; this specificity is given in human law, as formulated by prudent legislators. At the same time, the natural law is the standard for judging the justice of human laws; this act of criticism is accomplished in part by

39. Summa theologiae 1-2.95.2. I acknowledge the help of the English Dominican Fathers' translation in guiding my own.

40. Ibid.

41. Summa theologiae 1-2.96.4.

42. Summa theologiae 1-2.92.1.

43. Summa theologiae 1-2.94.3 and 96.3. Not all the vices are punished under human law, however, lest the law become too burdensome and contempt for it be taught (96.2 corp. and ad 2). 
assuring that the ends of human law coincide with the ends to which we are ordered by the natural law.

I want to break stride at this point by going back to a description I have given concerning discovery of the natural law. I have said that the process of discovering the natural law is a gradual one: it is a "historical narrative" involving reflection on who we are as a species and within community, reflection that is onguing and corrigible. Such a process entails the activity of practical reason operating both on the level of the individual moral agent and, also importantly, on the level of the legislators and leaders of whole communities (within the scope of human law as well). Let me try to make some more specific remarks about this narrative process, and about what facilitates this process. My remarks here can only be openended and provisional; they will diverge from exegesis of Aquinas at key points, but (it is to be hoped) only to return with illumination.

First, determining what we are as a species must be a historical business. Knowledge of human nature is acquired gradually, by experience and reflection. No simple or intuitive path can arrive at an adequate account of what we are as creatures and of what conduces to our flourishing. Thus of course is there even less a way to derive precepts in a simple manner from knowledge of our natures. There can be no "reading off" of what to do from claims about our essence or character. Such claims are hard-won and subject to revision; what practical guidance such claims yield to us is likewise only carefully drawn out.

Second, discovery of the natural law, as I take Thomas to describe it, is extended through time and involves ongoing experience on both the individual and social levels. This narrative process of discovery coincides with, or rather presupposes, the narrative structure of human experience itself. The life of an individual, or of a community, is best represented in the terms of a story: this is the genre that most aptly captures the form of human experience. As Augustine notes in the Confessions, the very fact that our experience is distinguished in terms of past, present, and future is a wonder and a puzzle. Our lives are not only made up of a continual flow of sensations. They are also characterized by the intentions and projects that link the moment of the present with past and future actions, intentions, and projects. 
In this regard, characterizing our temporal experience as a series of atomistic "moments" is unhelpful and obtuse. The "feel" of our time is not atomistic. It has duration, as well as linkage with the past and projection into the future. 44

Likewise, it may only be by the living out of our plans and intentions that we can come to understand what we were seeking in those very plans and intentions. As Abigail Rosenthal puts it, "At minimum, a story is a purpose transformed into enough experience to allow that purpose to understand itself a little better." 45 This helps us to see why discovery of the natural law must be time-bound (and why our conclusions about it must be open to revision). It is in the pursuit (and, often, possession) of goods that we learn about what we did or did not really desire. This is of course a kind of self-discovery. Also important to remember is that our conceptions of goods, let alone our conceptions of the virtues, are always themselves particularized within a community or at the least a life. Reasoning, then, about what we need to flourish will, then, always be reasoning about particular goods in particular contexts. This is part of the practical nature of this inquiry.

Third, can we say anything general about the nature of these particular inquiries? Alasdair MacIntyre, in his own discussion of narrative in After Virtue, notes that the narrative stories of our individual lives share at least two common features: they are teleological, i.e., they aim at an end or goal; and they are unpredictable, i.e., subject to chance and to the intervention of others. Thus MacIntyre goes on to claim that the moral life is essentially a quest, a quest searching for what the good is for us, both as individuals and as members of humanity. He notes rightly that "a quest is always an education both as to the character of that which is sought and in self-knowledge." 46 For this

44. I wish to acknowledge my indebtedness in these matters to Stephen Crites, "The Narrative Quality of Experience," Journal of the American Academy of Religion 39 (1971): 291-311. My discussion compresses many of the points he makes at greater length.

45. Abigail Rosenthal, A Good Look At Evil (Philadelphia: Temple University Press, 1987), p. 13. Rosenthal uses in this book the notion of narrative as a way of describing different sorts of evil human "types."

46. See Alasdair MacIntyre, After Virtue (Notre Dame: University of Notre Dame Press, 1981), p. 204. My discussion of MacIntyre is drawn from his chapter 15. 
reason MacIntyre gives the virtues such emphasis: they enable us to live out our questions well, to succeed at our quest. For reasoning well about our good (discovering the natural law in my understanding of Aquinas) as a quest is not a process that goes on in a vacuum. We do this work in the midst of, and about, the experiences and choices that constitute and shape our lives. This work occurs within and about the joys and sorrows, the suffering, the anxiety, the exhilaration, the ambiguity, and even the terror of living the moral life. Quests are taxing, trying affairs. About this Nussbaum has been right to stress the need for courage and for tolerance of ambiguity in the moral life. Behind or beneath this, however, I want to stress the commitment necessary to make possible the kind of inquiry I am describing. One must first believe the inquiry has a point, that how we live matters (and perhaps this is what MacIntyre means when he says that our lives are teleological). Quests, after all, are undertaken; we must begin by accepting the charge of inquiry. Our commitment to the inquiry begins to make possible the process of reflection, let alone the fear and trembling, of the discovery of the natural law.

Fourth, we began with claims concerning the narrative structure of experience and the narrative discovery of the natural law. But as we all learn, one fundamental aspect of our experience, and the fate of all plans we make and live out in experience, is the role of fortune in completing or confounding our plans. And if human experience is subject to chance, then we must wonder to what degree Fortune plays a part. MacIntyre himself opens up this question in After Virtue, in part to suggest that individual quests for the good may go unfinished, being interrupted by death. ${ }^{47}$ But how seriously may misfortune impair our pursuit of the inquiry about the good? Recall that Aquinas denies that all knowledge of the natural law can be expunged from the human heart; he concedes cirat human community and passion can obscure the "particulars" of the law. 48 We are back in some way to the old Aristotelian problem concerning the necessity of proper moral upbringing for progress in virtue. If we give tragedy its full due, is it not possible that certain personal histories are too bereft of right teaching, too full of corrupt influence, to engender the questions that launch us on the quest for our good? About the natural law, we might

47. See MacIntyre, After Virtue, pp. 197-198.

48. Summa theologiae 1-2.94.4. The word Aquinas uses for "particulars" or "details" is propria. 
ask if it can produce a just person from an unjust city. ${ }^{49} \mathrm{My}$ sense is that Thomas would deny this contingency; God's providence governs even Fortuna. Thomas certainly does deny the possibility of simple moral perplexity, in which a moral agent, without prior fault, cannot help but do wrong. I am not satisfied with this profession of faith in providence, so I raise it as a question.

In conclusion, let me multiply the senses of narrative to be recognized in Thomas. I have spoken in this essay of the natural law and the ongoing, narrative acquisition of knowledge of it. It is ongoing (1) in our coming to understand more about our natures and (2) in our coming to understand what means to choose in constituting the flourishing of our natures. Thomas repeatedly indicates that our inquiry regarding the natural law takes place socially and over time. Such indications include how prudence, which requires experience, is necessary for knowledge of the natural law. They also include his remarks about the Germans and how cultural (and moral) impediments to our knowledge of the natural law can exist. ${ }^{50}$ Add to this the fact that human law is needed to articulate and to specify the natural law for particular communities. Thus citizens of communities will encounter present understandings of the natural law within the rules (and customs) of their own societies.

But my scenario of ongoing acquisition of (our knowledge of) the natural law is too simple as it now stands. Thomas builds into his account of law a fourth type, one that also is derived from the eternal law (divine providence), but that stands in curious relationship to the natural law itself. This fourth type is the divine law, the law that is revealed by God. This revelation comes in two distinct parts, the Old Law and the New Law. It is necessary, Thomas tells us, because natural law does not suffice to order us to God; although our inclinationes direct us to "connatural" goods, God alone can completely satisfy us, and God is utterly beyond the reach of our powers. Thus the divine law aids us so that we may attain God. ${ }^{51}$

Moreover, humankind suffers under the burden of sin, one manifestation of which Thomas also characterizes as a quasi-law. 52 The lex fomitis is the law of concupiscence (literally, the law of tinder

49. Or, to name a community even more proximate, from an unjust family?

50. See Summa theologiae 1-2.94.4 and 6.

51. Summa theologiae 1-2.91.4.

52. Summa theologiae 1-2.91.6. 
or kindling - the fire in the flesh that is not completely subject to reason). It is a consequence of our primordial rejection of God, and thus the unruliness of our passions constitutes a further block to our pursuit of the good, even as understood in terms of the natural law. Thus our natural powers are not only limited; they are infirm. Divine law is necessary as a remedy for the effects of sin.

Thomas thus stresses not only the general social and historical nature of our inquiry and pursuit of the good; he indicates that there is one very specific community and history to which we all belong. We are children of Adam and Eve, and the history of us all is located within salvation history. Thus the narrative of Scripture is authoritative in its explanatory power of our condition (and that condition's remedy). 53

Going one step further: Is there in Thomas a place for the deployment of stories within the work of ethics? Recall what was said earlier regarding the narrative structure of human experience itself. It would then seem that stories, speaking now of human constructs apart from Scripture, are powerful shapers and informers of the selfunderstanding of individuals and communities, being reflective of the fundamentally narrative character of human experience. These might serve as imaginative guides for us in the structuring and interpreting that must make up personal and communal histories. That Scripture is clearly the most authoritative story for Thomas need not entail the exclusion of other stories (either creative artifacts or histories) as influences or educators. Indeed, such stories would resemble Scripture in their use of metaphor and example. ${ }^{54}$ Still there is a question: Does Thomas's own understanding of moral theology accommodate such a use of narrative? Can it as well supply an account of how such narratives would stand in relation to, or be integrated into,

53. See, for example, how Aquinas "reads" the infidelity of the Hebrews to the Decalogue (reducible to the natural law): "[God] decided to give human beings a Law which they could not fulfill of their own power so that, when they relied upon themselves they would discover that they were sinners, and, humiliated, would have recourse to the help of grace" (Summa theologiae 1-2.98.2 ad 3, after the Blackfriars translation). What we discover in reflection upon our natures is not just the natural law but also the fact that we cannot, and will not, do what we know is our good.

54. See Thomas's remarks about the appropriateness of the use of metaphor in Scripture, Summa theologiae 1.1.9. 
philosophical argument per se? These concerns take us well beyond the scope of this present essay, but an answer to them would contribute to a richer understanding of Thomistic ethics as well as Thomistic method. 55

Emory University

55. I gratefully acknowledge the support of the University Research Council of Emory University in giving me the leave time to pursue my study of Thomistic ethics. In a work in progress I am pursuing this last question regarding the senses of narrative in Aquinas. 